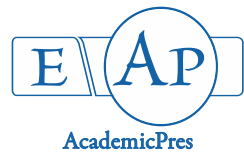

\title{
Characterization of Ocimum tenuiflorum (Linn.) Morpho-types Using RAPD Markers
}

\author{
James T. OPOOLA*, Matthew OZIEGBE \\ Obafemi Awolowo University, Faculty of Science, Department of Botany, Ile-Ife, \\ Nigeria; toluwaseopoola@gmail.com ("corresponding author); oziegbem@oauife.edu.ng
}

\begin{abstract}
Ocimum tenuiflorum Linn. (Lamiaceae) is an aromatic plant with a lot of potential medicinally, industrially and domestically. There are different morpho-types of $O$. tenuiflorum, with different shades of purple pigment on their leaves. Very few studies have been done to study the genetic variation among $O$. tenuiflorum morpho-types. Thus, in the present study, four O. tenuiflorum morpho-types that varied in pigmentation were characterised using RAPD marker as a molecular tool. Eight different primers collectively amplified 64 bands in the four morpho-types analysed. The RAPD technique revealed that the varied amount of purple pigment in $O$. tenuiflorum morpho-types is not due to environmental factor alone. The UPGMA clustering algorithm based on RAPD data grouped the four morpho-types into two major groups, with O. tenuiflorum (T2) with very light purple leaves and stem morpho-type, more related to $O$. tenuiflorum (T3) that have deep purple leaves and stem. The result was able to show the phylogenetic relationships within the species. The low level of genetic diversity observed in $O$. tenuiflorum can be attributed to the mode of reproduction and the reproductive biology of the species, due to the fact that they are likely to be natural hybrids produced through cross pollination.
\end{abstract}

Keywords: morpho types; Ocimum tenuiflorum; primers; RAPD

\section{Introduction}

Ocimum tenuiflorum Linn. (Lamiaceae) is an aromatic plant with about 150 variants. It is one of the most famous perennial herbs which are native to India and widespread as a cultivated plant and an escaped weed, covering the entire Indian sub-continent (Kirtikar and Basu, 1984). It is largely distributed in Asia, Australia and West Africa and also in some Arabian countries, mainly in drier sandy areas (Pistrick, 2001). O. tenuiflorum is also known as O. sanctum. It is called Indian's holy basil in English, 'Kala-Tulsi' among the Hindi-speaking people of India and 'Efinrin wewe' among the Yoruba speaking people of South-western Nigeria (Mohan et al., 2011).

It is an erect, tall, sub-shrub plant, with hairy subquadrangular branches. Leaves are simple, ranging from shades of green to purple. The leaves can be ovate, ellipticoblong, obtuse or acute in shape. The aerial parts possess glandular hairs on stalked and sessile glands which secrete volatile oils. The inflorescence has purplish-white, hermaphroditic and zygomorphic flowers arranged in elongate racemes in close whorls. They produce numerous tiny seeds which are dark brownish and globose-subglobose in shape with shinny seed coat. O. tenuiflorum is readily distinguished from the other species in the genus Ocimum by their characteristically spreading pedicels and the internally glaborous calyces (Malav, 2015).

The variants of $O$. tenuiflorum with different coloured flowers, with combinations of purple or green calyces and purple or white corolla are available. Four main morphotypes have been identified in South-west Nigeria. Morphologically indistinguishable types represented from diverse ecological regions had variable chemical constituents (Ali and Ali, 2012). A wide variability within different traits was observed in accessions of population from diverse phyto-geographical regions varying in climate, habit and morphology (Malav, 2015). The variability observed in Ocimum sanctum genotypes on the basis of morphomolecular investigations indicated the genetic diversity among natural populations/genotypes found in the district Poonch, Azad Kashmir (Ahmad and Khaliq, 2002). Variability based on pigmentation exists also within the morpho-types of $O$. tenuiflorum. Despite the potential of pigmented traits as genetic markers, no concrete genetic studies have been done on these traits on $O$. tenuiflorum in Nigeria. 
418

\section{Materials and Methods}

\section{Plantmaterial}

Fresh leaves of four morpho-types of $O$. tenuiflorum i.e., $O$. tenuiflorum (green leaves and stem) which was tagged $\left(\mathrm{T}_{1}\right)$, O. tenuiflorium (very light purple leaves and stem) $\left(\mathrm{T}_{2}\right)$, O. tenuiflorum (deep purple leaves and stem) $\left(\mathrm{T}_{3}\right)$ and $O$. tenuiflorum (light purple leaves and stem) ( $\left.\mathrm{T}_{4}\right)$ were collected at the experimental garden of the Department of Botany, Obafemi Awolowo University, Ile Ife, Nigeria.

\section{DNA extraction}

Total genomic DNA was extracted from fresh leaf tissues by the method of Doyle and Doyle (1990) with slight modification as explained below.

The samples were prepared by putting approximately $100 \mathrm{mg}$ of fresh leaf tissues into an extraction tube. Two steel balls were added each into the tube to enable grinding. The tissues were ground into fine powder by using Genogrinder-2000. Thereafter, $450 \mu \mathrm{l}$ of pre-heated plant extraction buffer was added. Incubation of the tubes was done at $65^{\circ} \mathrm{C}$ for $20 \mathrm{~min}$ after which the tubes were mixed by occasionally inverting them to homogenize the sample. The tubes were removed and allowed to cool for $2 \mathrm{~min}, 200$ $\mu \mathrm{l}$ of ice-cold $5 \mathrm{M}$ potassium acetate was then added. The tube was incubated on ice for $20 \mathrm{~min}$ to precipitate protein and centrifuged at $3,500 \mathrm{rpm}$ for $10 \mathrm{~min}$ and the supernatant was then transferred into freshly labeled tubes. Then, $2 / 3$ volume of ice-cold isopropanol was added into the tubes, mixed gently and incubated at $-80^{\circ} \mathrm{C}$ for $15 \mathrm{~min}$ to precipitate the DNA. It was then centrifuged at 3,500 $\mathrm{rpm}$ for $15 \mathrm{~min}$. The supernatant was decanted until the last drop. About $400 \mu \mathrm{l}$ of $70 \%$ ethanol was added to wash the DNA pellet, then centrifuged at 3,500 rpm for $15 \mathrm{~min}$. The supernatant was decanted until the last drop and the pellet was air dried (until ethanol smell disappears). $60 \mu \mathrm{l}$ of ultrapure water or (low salt TE) was added to re-suspend the DNA. $2 \mu \mathrm{l}$ of RNase was added and incubated at $37^{\circ} \mathrm{C}$ for 30-40 min. In order to check the DNA quality and removal of RNA, $0.8 \%$ agarose gel was prepared by boiling $0.8 \mathrm{~g}$ of agarose in $100 \mathrm{ml}$ of $1 \mathrm{X} \mathrm{TBE}$, and allowed to cool at $60^{\circ} \mathrm{C}$; then, $5 \mu$ l ethidium bromide was added and gently swiped to mix, the solution was poured on the gel tray before it polymerizes. $3 \mu \mathrm{l}$ of DNA and $3 \mu \mathrm{l}$ of loading dye were mixed together and $6 \mu \mathrm{l}$ of the mixture was loaded on to the $0.8 \%$ agarose gel. The gel was run at $80 \mathrm{~V}$ for $60 \mathrm{~min}$ and the gel picture was saved. When the RNA was completely removed it was then proceed to the Nanodrop. DNA concentration was quantified using DNA-50 option of the Nano drop spectrophotometer.

\section{PCR condition}

PCR reaction was performed using eight commercial primers (Table 1). Optimal conditions for RAPD analysis were determined by the highest number of fragments and accurate bands. PCR was performed in a $25 \mu \mathrm{l}$ volume of reaction mixture (Williams et al., 1990) containing $1 X$ Taq polymerase buffer (with $25 \mathrm{~mm} \mathrm{MgCl}_{2}$ ), 0.6 units of Taq DNA polymerase, $5 \mathrm{~mm}$ dNTPs, $10 \mathrm{~mm}$ of ransom decamer primer (Finnzymes) and $15 \mathrm{mg}$ of total genomic DNA. Amplifications were carried out using a DNA thermo cycler (Bio-Rad Laboratories, USA) with the following parameters: 1 cycle of $4 \mathrm{~min}$ at $94^{\circ} \mathrm{C}$ followed by 45 cycles of $1 \mathrm{~min}$ at $94^{\circ} \mathrm{C}, 1 \mathrm{~min}$ at $37^{\circ} \mathrm{C}$ and $2 \mathrm{~min}$ at 72 ${ }^{\circ} \mathrm{C}$. The last extension cycle was programmed at $72^{\circ} \mathrm{C}$ for 7 min. The PCR products were resolved on a $1.5 \%$ agarose gel containing $0.4 \mathrm{mg} / \mathrm{L}$ ethidium bromide and the photograph was taken and documented.

\section{Statistical analysis}

The position of the amplified bands was compared for each morpho-type and primer combination. The nonreproducible and ambiguous bands were eliminated. The photograph was converted into a binary matrix using " 1 " and " 0 " characters. The bands were scored " 1 " for presence and " 0 " for absence. Further analysis was done by calculating the Pairwise Nei Genetic Distance and Pairwise Nei Genetic Identity using Genalex 6.502 software and MEGA 7 software. The dendogram was constructed using the Unweighted Pair Group Method using Arithmetic means (UPGMA) (Sokaland Sneath, 1973).

\section{Results}

In the present study, four O. tenuiflorum morpho-types were surveyed with RAPD marker system. Eight arbitrary primers were used and they were all polymorphic. The 8 primers used gave a total of 64 bands across the 4 morphotypes. The number of total amplicons varied from 13 for $O$. tenuifllorum $\left(\mathrm{T}_{1}\right)$ to 20 for $O$. tenuiflorum $\left(\mathrm{T}_{3}\right)$. O. tenuiflorum $\left(\mathrm{T}_{1}\right)$ morpho-type, $O$. tenuiflorum $\left(\mathrm{T}_{2}\right)$ morpho-type and $O$. tenuiflorum $\left(\mathrm{T}_{4}\right)$ morpho-type had the same number of private bands (3) (bands that are unique to each morpho-type and cannot be found in any other morpho-type), whereas $O$. tenuiflorum $\left(\mathrm{T}_{3}\right)$ morpho-type had one more private band (4) than the other morpho-types studied. O. tenuiflorum $\left(\mathrm{T}_{3}\right)$ morpho-type had the highest number of common bands (16), followed by $O$. tenuiflorum $\left(\mathrm{T}_{4}\right)$ morpho-type (14), then by $O$. tenuiflorum $\left(\mathrm{T}_{2}\right)$ morpho-type (11), while $O$. tenuiflorum $\left(\mathrm{T}_{1}\right)$ morpho-type produced the lowest number of common bands (10).

\section{Discussion}

The result of Pairwise Nei Genetic Distance analysis is presented in Table 2. A dendogram was constructed based on pairwise morpho-type matrix using Unweighted Pair Group Method with Arithmetic averages (UPGMA) (Sokal and Sneath, 1973). The tree (dendogram) with the sum of branch length of 1.42240475 is shown in Fig. 1. The tree is drawn to scale, with branch lengths (next to the branches) in the same units as those of Nei Genetic Distances used to infer the phylogenetic tree.

The UPGMA clustering algorithm based on RAPD data grouped the four morpho-types into two major groups (Fig. 1), with $O$. tenuiflorum $\left(\mathrm{T}_{1}\right)$ morpho-type and $O$. tenuiflorum $\left(\mathrm{T}_{4}\right)$ morpho-type in one group and O.tenuiflorum $\left(\mathrm{T}_{2}\right)$ morpho-type and $O$. tenuiflorum $\left(\mathrm{T}_{3}\right)$ morpho-type in the other group. Based on the Pairwise Nei Genetic Distance analysis of the RAPD data, it can be stated that $O$. tenuiflorum $\left(\mathrm{T}_{1}\right)$ morpho-type is more related to $O$. 
Table 1. List of primers used and their sequence

\begin{tabular}{|c|c|c|}
\hline Primers & & Sequence \\
\hline OPB03 & $5^{1}-\mathrm{CAT}$ & CCC CCT $\mathrm{G}-3^{1}$ \\
\hline OPB08 & $5^{1}-\mathrm{GTG}$ & CAC ACG $\mathrm{G}-3^{1}$ \\
\hline $0 \mathrm{~PB} 13$ & $5^{1}-\mathrm{TTC}$ & CCC CGC $\mathrm{T}-3^{1}$ \\
\hline OPB14 & $5^{1}-\mathrm{TCC}$ & GCT CTG $\mathrm{G}-3^{1}$ \\
\hline $\mathrm{OPH} 05$ & $5^{1}-\mathrm{AGT}$ & CGT CCC $\mathrm{C}-3^{1}$ \\
\hline OРТ01 & $5^{1}-\mathrm{GGG}$ & CCA CTC $\mathrm{A}-3^{1}$ \\
\hline OPT17 & $5^{1}-\mathrm{CCA}$ & ACG $\quad$ TCG $T-3^{1}$ \\
\hline ОРТ20 & $5^{1}-\mathrm{GAC}$ & CAA TGC $\mathrm{C}-3^{1}$ \\
\hline
\end{tabular}

Table 2. Pairwise O. tenuiflorum morpho-types matrix of Nei genetic distance

\begin{tabular}{ccccc}
\hline & $\mathrm{T}_{1}$ & $\mathrm{~T}_{2}$ & $\mathrm{~T}_{3}$ & \\
\hline $\mathrm{T}_{1}$ & 0.000 & & & \\
$\mathrm{~T}_{2}$ & 0.624 & 0.000 & 0.000 \\
$\mathrm{~T}_{3}$ & 1.030 & 0.767 & 0.963 & 0.000 \\
$\mathrm{~T}_{4}$ & 0.442 & 0.934 &
\end{tabular}

$\left(\mathrm{T}_{1}\right)$ O. tenuiflorum with green leaves and stem, $\left(\mathrm{T}_{2}\right)$ O. tenuiflorium with very light purple leaves and stem, $\left(\mathrm{T}_{3}\right)$ O. tenuiflorum with deep purple leaves and stem), ( $\left.\mathrm{T}_{4}\right)$ O. tenuiflorum with light purple leaves and stem
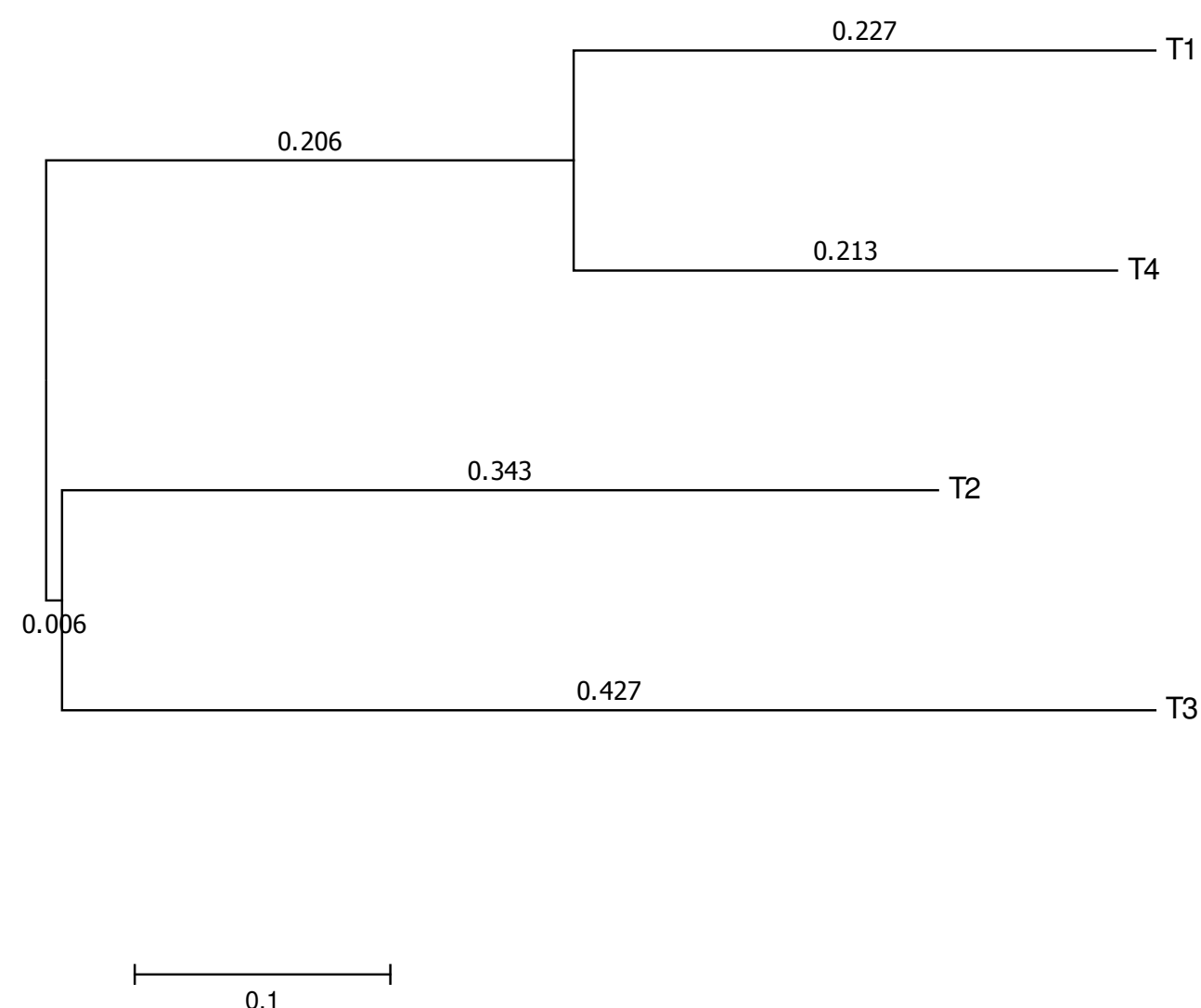

Fig. 1. The UPGMA clustering algorithm based on RAPD data of $O$. tenuiflorum morpho-types; $\left(\mathrm{T}_{1}\right)$ O. tenuiflorum with green leaves and stem, $\left(\mathrm{T}_{2}\right)$ O. tenuiflorium with very light purple leaves and stem, $\left(\mathrm{T}_{3}\right)$ O. tenuiflorum with deep purple leaves and stem), ( $\left.\mathrm{T}_{4}\right)$ O. tenuiflorum with light purple leaves and stem 
420

tenuiflorum $\left(\mathrm{T}_{4}\right)$ morpho-type than $O$. tenuiflorum $\left(\mathrm{T}_{2}\right)$ morpho-type and $O$. tenuiflorum $\left(\mathrm{T}_{3}\right)$ morpho-type.

Also, O. tenuiflorum $\left(\mathrm{T}_{2}\right)$ morpho-type is more related to $O$. tenuiflorum $\left(\mathrm{T}_{3}\right)$ morpho-type than $O$. tenuiflorum $\left(\mathrm{T}_{1}\right)$ morpho-type and $O$. tenuiflorum $\left(\mathrm{T}_{4}\right)$ morpho-type (Fig. 1).

The results from the present study revealed that RAPD markers successfully differentiated the four morpho-types of $O$. tenuiflorum. The number of polymorphic bands indicated genetic variation within $O$. tenuiflorum morphotypes, which showed that the morphological variations were genetic. In the hereby study, the size of amplified fragments varied within the different primers used; this result is in correlation with the study of Ibrahim et al. (2013) who observed genetic dissimilarity among the morpho-types of Ocimum studied using morphological traits and RAPD markers. Savat et al. (2016) also reported substantial genetic variation within species and between species. They concluded that the genetic base of Ocimum genus is quite broad. In the current study, the number of genetic loci detected with RAPD markers are much higher than those detected with morphological and biochemical markers. Jakar et al. (2015) reported the usefulness of molecular study in differentiating individuals that are closely related.

The low level of genetic diversity observed in $O$. tenuiflorum can be attributed to the mode of reproduction and the reproductive biology of the species, due to the fact that they are likely to be natural hybrids produced through cross pollination (Oziegbe et al., 2016). Individuals that undergo cross pollination have higher gene diversity compared with elf-pollinating species (Alvarez et al., 2001).

\section{Conclusions}

The identification of primers that can apparently generate species specific profiles is significant for further phylogenetic studies in Ocimum. RAPD techniques indicated that it is useful in estimation of polymorphism and phylogenetic relationships among $O$. tenuiflorum morpho-types. The polymorphism data generated can be used for further breeding and characterisation of the species.

\section{Conflict of Interest}

The authors declare that there are no conflicts of interest related to this article.

\section{References}

Ahmad SD, Khaliq I (2002). Morpho-molecular variability and heritability in Ocimum sanctum genotypes from Northern regions of Pakistan. Pakistan Journal of Biological Sciences 5:10841087.

Ali A, Ali M (2012). New fatty acid derivatives from Ocimum sanctum L. leaves. Department of Phamacognosy and Phytochemistry, Faculty of Pharmacy,Jamia Hamdad, New Delhi.

Alvarez AE, Van da Wiel CMM, Smulders MJM Vosman B (2001). Use of microsatellites to evaluate genetic diversity and species relationships in the genus Lycopersicon. Theoretical Applied Genetics 103:1283-1292.

Cantino PD (1992). Evidence for a polyphyletic origin of the Labiateae. Annals of the Missouri Botanical Garden 79:361-379.

Cantino PD, Sanders RV (1986). Subfamiliar classification of Labiateae. Systematic Botany 11:163-185.

Carovic-Stanko K, Orlic S, Politeo O, Strikic F, Kolak I, Milos M, Satovic Z (2010). Composition and antibacterial activities of essential oils of seven Ocimum taxa. Food Chemistry 119(1):196-201.

Doyle JJ, Doyle JL (1990). A rapid total DNA preparation procedure for fresh plant tissue. Phytochemical Bulletin 19:11-15.

Erum J, Khan N, AhmadZ, Ghaffor A (2011). Genetic diversity and disease response of rust in bread wheat collected from Waziristan Agency, Pakistan. International Journal of Biodiversity Conservation 3(1):10-18.

Ibrahim MM, Aboud KA, Al-Ansary AMF (2013). Genetic variability among three sweet basil (Ocimum basilicum L.) varieties as revealed by morphological traits and RAPD markers. World Applied Sciences Journal 24(11):1411-1419.

Jakhar R, Gaurav SS, Sigh KK (2015). Evaluation of genetic diversity using RAPD markers in Ocimum. HortFlora Research Spectrum 4(3):255259.

Jamoni K, Mohamed LK (2013). Commercial potentialities of essential oil of Ocimum members growing in North East India. International Journal of Pharmacy and Life Sciences 4(4):2559-2567.

Kirtikar L, Basu BD (1984). Indian medicinal plants. Vol. 1. Lalit Mohan Basu Allahabad, India.

Labra M, Vannini C, Grassi F, Bracale M, Balsemin M, Basso B, Sala F (2004). Genomic stability in Arabidopsis thaliana transgenic plants obtained by floral dip. Theoretical and Applied Genetics 109(7):15121518.

Mohan L, Amberkar MV, Kumari M (2011). Ocimum sanctum Linn. (Tulsi)- an overview. International Journal of Pharmaceutical Sciences Review and Research 7(1):51-53.

Oziegbe M, Kehinde TO, Matthew JO (2016). Comparative reproduction mechanisms of three species of Ocimum L. (Lamiaceae). Acta Agrobotanica 69(1):1648.

Paton A (1992). A synopsis of Ocimum L. (Labiatae) in Africa. Kew Bulletin $44(3): 403-435$.

Pistrick K (2001). Phenology and genome variation in Allium L. - a tight correlation? Plant Biology 3:654660.

Savat MC, Trigiano RN, Caetano G (2016). DNA amplification fingerprinting identifies closely related Ocimum species. Journal of American Society of Horticultural Science 121:1043-1048.

Sokal RR, Sneath PH (1973). Principle of numerical taxonomy. WH Freeman and $\mathrm{Co}$, San Francisco and London.

Williams JGK, Kubelik AR, Livak KJ, Rafalski JA, Tingey SV (1990). Polymorphisms amplified by arbitrary primers as useful as genetic markers. Nucleic Acids Research 18:6531-6535. 